\title{
Muscle Response to the Association of Statin and Physical Exercise in Rats
}

\author{
Respuestas Musculares de la Asociación de Estatina y Ejercicio Físico Aeróbico en Ratas
}

\begin{abstract}
"Mariana Rotta Bonfim; "Camargo Filho José Carlos Silva; "Luiz Carlos Marques Vanderlei; **Susimary Aparecida Trevizan Padulla; ${ }^{* * *}$ Marilita Falângola Accioly; ${ }^{* * *}$ Dorotéia Rossi Silva Souza \& ${ }^{* * *}$ Reinaldo Azoubel
\end{abstract}

BONFIM, M. R.; CAMARGO FILHO, J. C. S.; VANDERLEI, L. C. M.; PADULLA, S. A. T.; ACCIOLY, M. F.; SOUZA, R. S. D. \& AZOUBEL, R. Muscle response to the association of statin and physical exercise in rats. Int. J. Morphol., 27(4):1155-1161, 2009.

SUMMARY: Physical exercise and statins, which are recommended for the treatment of dyslipidemia, are independently associated to the occurrence of muscle injury. The objective is analyze the effect of aerobic exercise associated to the use of simvastatin on the morphology of the gastrocnemius muscle. Thirty Wistar rats were divided into six groups, two of which received a standard diet (1 sedentary and 1 exercised) and four ( 1 sedentary with medication, 1 sedentary without medication, 1 exercised with medication, 1 exercised without medication) received a hypercholesterolemic diet (standard diet with the addition of cholesterol and coconut oil). Simvastatin $(20 \mathrm{mg} / \mathrm{Kg}$ ) was administered five days a week for eight weeks, together with aerobic training on a treadmill (9.75 m/min) for 60 minutes a day. The gastrocnemius muscle was removed, sliced, stained with Hematoxylin-Eosin and submitted to a histochemical reaction to determine mitochondrial activity. The data were analyzed using a paired t-test, analysis of variance and Scheffé's post hoc test $(\mathrm{p}<0.05)$. Greater histological alterations were found in the medicated and exercised animals, with a greater frequency of occurrence as well. The histochemical analysis revealed that the medicated groups had fibers with more intensive mitochondrial activity alongside fibers with an absence of reaction. The morphometric analysis revealed no significant differences between groups. It is suggested that simvastatin is a medication that leads to the occurrence of muscle injury and its administration in association with physical activity may exacerbate these injuries. This finding may be related to cellular respiration.

KEY WORDS: Hydroxymethylglutaryl-CoA Reductase Inhibitors; Exercise; Skeletal Muscle.

\section{INTRODUCTION}

Dyslipidemia is characterized by lipid metabolic abnormalities related to arteriosclerosis and is considered a conventional risk factor for cardiovascular disease (Sociedade Brasileira de Cardiologia, 2007). According to the 4th Brazilian Guidelines on Dyslipidemia and the Prevention of Arteriosclerosis, the treatment of dyslipidemia is one of the ways to reduce cardiovascular disease and involves nutrition therapy, physical activity and the administration of drugs (Sociedade Brasileira de Cardiologia).

Statins are the medication of choice for dyslipidemia, as such substances have demonstrated a positive relationship to a reduction in cardiovascular morbidity-mortality (Sociedade Brasileira de Cardiologia). These medications are also known as HMG-CoA reductase inhibitors and are characterized as substances that act on the synthesis of cholesterol, resulting in an adjustment of the lipid profile (Armitage, 2007). Statin is generally tolerated by the majority of patients. However, the increasing interest and concomitant increase in the prescription of this medication have lead to the detection of undesirable side effects, such as hepatotoxicity and myopathy (Tomlinson \& Mangione, 2005).

It has been suggested that the occurrence of myopathy associated to statin is related to the reduction in cholesterol and its direct effect on the mitochondrial respiratory chain, which produces changes in the calcium cycle of the sarcoplasmatic reticulum, resulting in apoptosis and oxidative stress as well as muscle remodeling and

\footnotetext{
* Post-Graduation Program of Physiotherapy, Faculty of Science and Technology (FCT/UNESP), Presidente Prudente/SP, Brazil

** Department of Physiotherapy, Faculty of Science and Technology (FCT/UNESP), Presidente Prudente/SP, Brazil

**** Post-Graduation Program, Faculty of Medicine of São José do Rio Preto (FAMERP), São José do Rio Preto/SP, Brazil
} 
degeneration (Tomlinson \& Mangione; Sirvent et al., 2008). Moreover, a number of studies have found that medication therapy with statin associated to physical exercise exacerbates muscle injuries and leads to a high concentration of creatine kinase (CK) (Thompson et al., 1997; Kearns et al., 2008). In a study with animals, Seachrist and collaborators found this association to lead to histological abnormalities characterized by muscle fiber and mitochondrial degeneration, fragmentation of the sarcoplasm and the presence of inflammatory infiltrates, which were found to be related to the inadequate use of energy (Seachrist et al., 2005).

Despite the evidence relating this practice to mitochondrial injury, the mechanism of action of this association in skeletal muscle remains unclear. In order to contribute to the literature on this subject, the aim of the present study was to determine histological, histochemical and morphometric alterations caused by the association of statin and physical exercise in rat skeletal muscle.

\section{MATERIAL AND METHOD}

Thirty male Wistar rats (Rattus novergicus) weighing between 180 and 200 grams were maintained in collective plastic cages in a controlled environment, with a mean temperature of $22 \pm 2{ }^{\circ} \mathrm{C}, 50 \pm 10 \%$ humidity and a 12-hour light/dark cycle (light cycle beginning at 7:00 am). All procedures received prior approval from the Ethic Committee of the Faculdade de Medicina de São José do Rio Preto (FAMERP - Process $n^{\circ}$ 5363/2005) and were in compliance with the Ethical Principles in Animal Experimentation adopted by the "Colégio Brasileiro de Experimentação Animal".

After 12 hours of fasting, the animals were randomly divided into six groups of five animals: standard diet and sedentary (SS); standard diet and exercised (SE); hypercholesterolemic diet and sedentary (HS); hypercholesterolemic diet and exercised (HE); hypercholesterolemic diet, sedentary and administration of medication (HSS); and hypercholesterolemic diet, exercised and administration of medication (HES). The animals in the standard diet groups were fed a conventional chow (Ração Probiotério - Primor $\left.{ }^{\circledR}\right)$. The animals in the hypercholesterolemic diet groups were fed a special diet based on the standard diet (AIN - $93 \mathrm{G}$ ), substituting soybean oil with $20 \%$ coconut fat and $1.25 \%$ cholesterol(8) in order to obtain lipid changes. Water and diet were provided ad libitum.

The diets were administered for 30 days. After 12 hours of fasting, blood samples were taken from the animals in the hypercholesterolemic diet groups in order to determi- ne lipid alterations. Serum levels of triglycerides (TG) and total cholesterol (TC) were determined by means of calorimetric enzyme methods and HDL-c levels were determined by selective precipitation of LDL-c and VLDLc (Cobas Mira S.). Levels of non-HDL cholesterol components were determined by the following formula: nonHDL-c = TC - HDL-c (Padulla et al., 2009).

The animals in the medicated groups received simvastatin ( $20 \mathrm{mg}$ ) (orally force fed) five days a week for eight weeks. Dosage was calculated using allometric extrapolation in accordance with the metabolism of each animal, with weekly adjustments based on body weight gain (Padulla et al.).

Animals in the exercised groups performed physical exercise for eight weeks on a treadmill designed for small animals. The exercise protocol described by Camargo Filho et al. (2005) was employed, consisting of two phases: Adaptation (daily walking sessions with a progressive duration for the first ten days) and Training (60-minute walking sessions five days a week for eight weeks at a speed of 9.75 meters per minute).

Seventy-two hours after the last exercise session, the animals were sacrificed by decapitation in a guillotine and the gastrocnemius muscle from the right pelvis was removed, the central fragment of the muscle was separated, frozen using the non-fixed tissue freezing method, stored at $-182^{\circ}$ $\mathrm{C}$ in liquid nitrogen and subsequently used for the mounting of slides with 8-mm slices. The slices were stained with Hematoxylin and Eosin, which was used for the histological analysis (shape, size, position of nuclei, coloration of sacroplasm and presence of hyperplasia) and the morphometric analysis of the lesser diameter of the muscle fibers (Image Pro-Plus software program - Media Cybernetics, Silver Spring, MD). Slices were also used for the histochemical demonstration of nicotinamide adenine dinucleotide tetrazolium reductase (NADH-TR) activity, in which the NADH-TR enzyme oxidizes NADH, thereby forming formazan deposits (dark blue coloration); these deposits have a more intense stain in sites of greater oxidative activity (Camargo Filho et al., 2005).

For the qualitative analysis, descriptions were made of the histological and histochemical (reaction intensity and formazan content) findings. In the quantitative analysis, frequency analysis was employed to assess the occurrence of changes in muscle morphology using the "absence or presence" classification, with the values expressed as percentage frequency. Data on lipid profile and morphometry were submitted to the Kolmogorov-Smirnov normality test and descriptive analysis, with values expressed as mean, stan- 
dard deviation and confidence interval. Differences in the pre-diet and post-diet lipid profile were determined using a paired t-test and morphology data were analyzed using analysis of variance (ANOVA), with differences determined by Scheffé's post hoc test. The level of significance was set at $\mathrm{p}<0.05$. The Statistical Package for the Social Sciences (SPSS) 13.0 software program was used for the statistical analysis.

\section{RESULTS}

Based on the results of the blood analyses used to determine lipid alterations after 30 days of ingesting the diet, there was only a significant change in total cholesterol and the non-HDL cholesterol component, which both increased. Changes in the other lipid components analyzed did not achieve any statistical significance between the pre-diet and post-diet periods (Table I).

Table I. Lipid profile analyzes of the animals fed with hypercholesterolemic diet.

\begin{tabular}{lccc} 
Lipid fraction & Pre-Diet & Post-Diet & P value \\
\hline Total choleste rol & $73,25 \pm 19,63$ & $98,1 \pm 34,44$ & 0,00 \\
Triglycerides & $71,61 \pm 41,30$ & $88,56 \pm 4,85$ & 0,38 \\
HDL cholest erol & $20,2 \pm 6,13$ & $19,9 \pm 6,92$ & 0,90 \\
Non-HDL cholesterol & $53,05 \pm 14,56$ & $78,2 \pm 34,04$ & 0,00
\end{tabular}

Table II. Frequency analysis (\%) of the presence of muscular changes on the slides of each animal group studied.

$\begin{array}{lcccccc}\text { Features } & \text { SS } & \text { SE } & \text { HS } & \text { HE } & \text { HSS } & \text { HES } \\ \text { Round fibers } & --- & 80 & 40 & 100 & 100 & 100 \\ \text { Angular fibers } & --- & 80 & 40 & 100 & 100 & 100 \\ \text { Polymorphic Fibers } & --- & 20 & 20 & 80 & 60 & 100 \\ \text { Atrophic fibers } & --- & 20 & --- & 20 & 60 & 60 \\ \text { Inflammatory } & --- & 100 & 40 & 80 & 40 & 100 \\ \text { Endomysial Edema } & --- & 100 & 20 & 80 & 20 & 80 \\ \text { Perimysial edema } & --- & --- & 20 & --- & --- & 60 \\ \text { Phagocytized Fibers } & --- & 40 & 20 & 60 & 20 & 80 \\ \text { Necrosis } & --- & 20 & --- & 20 & --- & --- \\ \text { Splitting } & --- & --- & --- & --- & 20 & 40\end{array}$

Regarding the histological findings, analysis of the slides revealed that the sedentary groups without medication exhibited morphology characterized by a normal fascicular pattern, normal perimysium and endomysium, normal, polygonal fibers and peripheral nuclei (Figs. 1a and 1b). The animals in the exercised groups without medication exhibited an altered fascicular pattern, perimysial and endomysial edemas, angular, polymorphic, atrophic fibers, the presence of inflammatory infiltrates and fibers in the process of phagocytosis and necrosis (Figs. 1c and 1d). The sedentary group fed with hypercholestolemic diet and having received the medication exhibited significant edemas, inflammatory infiltrates, round, angular, polymorphic fibers, the process of phagocytosis and loss of the sacrolemma (Fig. 1e). These same alterations were observed in the group fed the hypercholestolemic diet, having received the medication and performed exercise, which also exhibited the occurrence of splitting, fibers in a process of phagocytosis and atrophic fibers (Fig. 1f).

Frequency analysis revealed that the groups having received the medication had a greater frequency of atrophic fibers and the group having received the medication and performed exercise had a greater occurrence of splitting. Moreover, the sedentary group having received simvastatin had a high frequency of alterations in the shape of the muscle fibers, with a similar frequency in the exercised groups; this characteristic was not found in the other sedentary groups (Table II).

Regarding the histochemical analysis, the sedentary groups without medication had a normal pattern in the majority of fibers for the NADH reaction (Figs. 2a and 2b). The exercised groups without medication exhibited fibers with increased enzyme activity, characterized by the presence of blue-stained granules (formazan) deposited in the sites of the mitochondria, generally in the peripheral regions of the cells (Fig. 2c and 2d).

The hypercholestolemic diet groups that received the medication and remained sedentary exhibited a large amount of amorphous aggregates in the subsarcolemma position as well as a number of fibers with a loss of enzyme activity (Fig. 2e). However, the hypercholestolemic diet group that received the medication and performed exercise exhibited a greater amount of amorphous formazan aggregates located alongside fibers with a loss of enzyme activity (Fig. 2f). 
Table III. Values of mean \pm standard deviation (SD) and confidence interval (CI) of the fiber morphometry $(\mu \mathrm{m})$ of each groups studied.

\section{Confidence Interval - 95\%}

\begin{tabular}{lccc} 
& Mean \pm SD & Minimum & Maximum \\
\cline { 3 - 4 } SS & $48,42 \pm 0,87$ & 47,04 & 49,80 \\
SE & $44,54 \pm 3,98$ & 39,59 & 49,49 \\
HS & $40,72 \pm 6,67$ & 32,43 & 48,99 \\
HE & $42,39 \pm 5,85$ & 35,12 & 49,66 \\
HSS & $47,53 \pm 5,98$ & 40,11 & 54.96 \\
HES & $39,07 \pm 2,71$ & 35,70 & 42,44
\end{tabular}
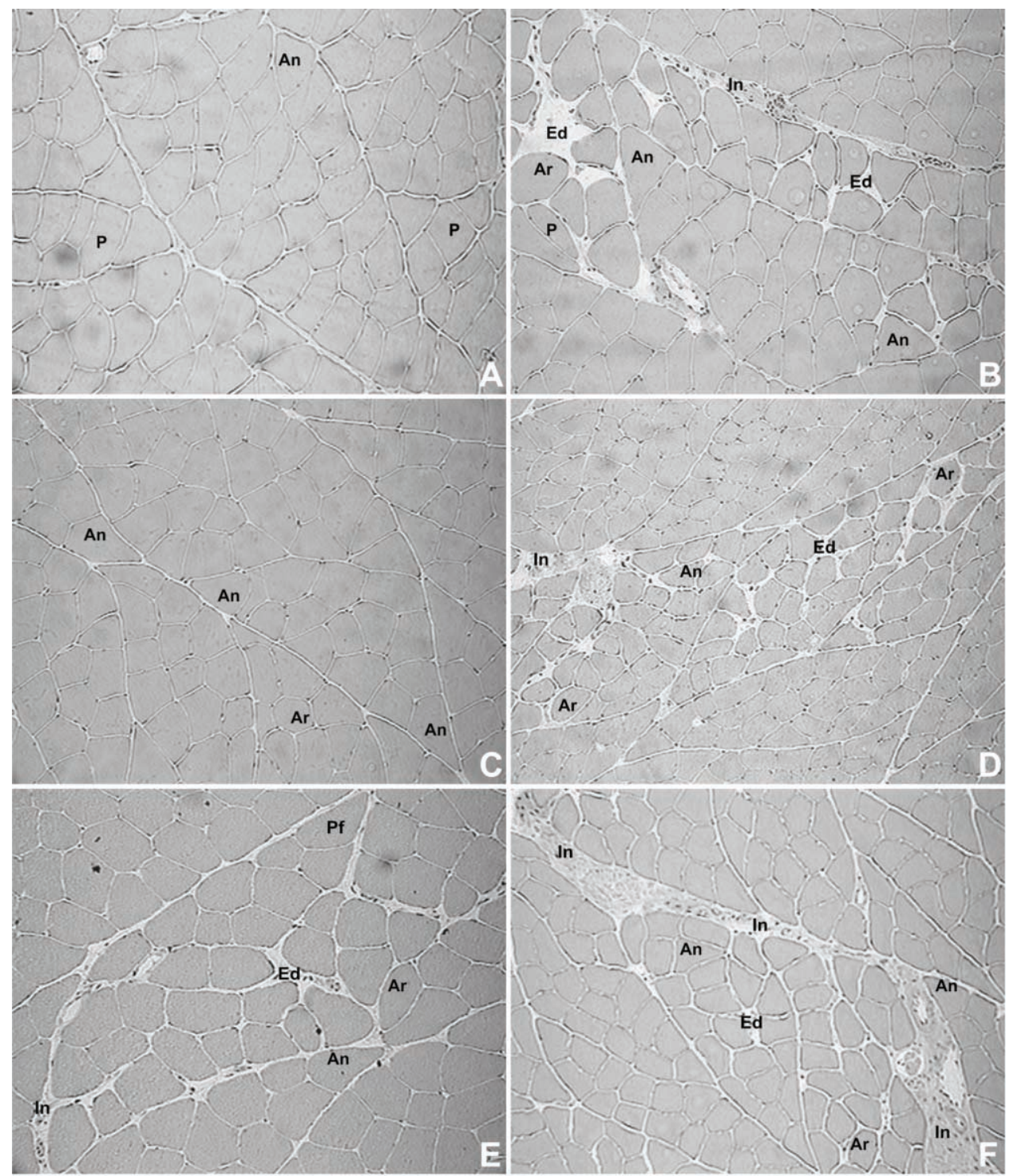

Analysis of the diameter of the muscle fibers revealed no significant differences between groups (Table III).

Figure 1. Cross-sectional of rat gastocnemius muscle fibers.

A) Standard Diet and Sedentary;

B) Standard Diet and Exercised;

C) Hypercholesterolemic Diet and Sedentary;

D) Hypercholesterolemic Diet and Exercised;

E) Hypercholesterolemic Diet, Sedentary and Simvastatin;

F) Hypercholesterolemic Diet, Exercised and Simvastatin.

HE. 200X.

Polygonal Fibers (P);

Round Fibers (Ar);

Angular Fibers (An);

Polymorphic Fibers (Pf);

Atrophic Fibers (At);

Edema (Ed);

Inflammatory Infiltrates (In). 

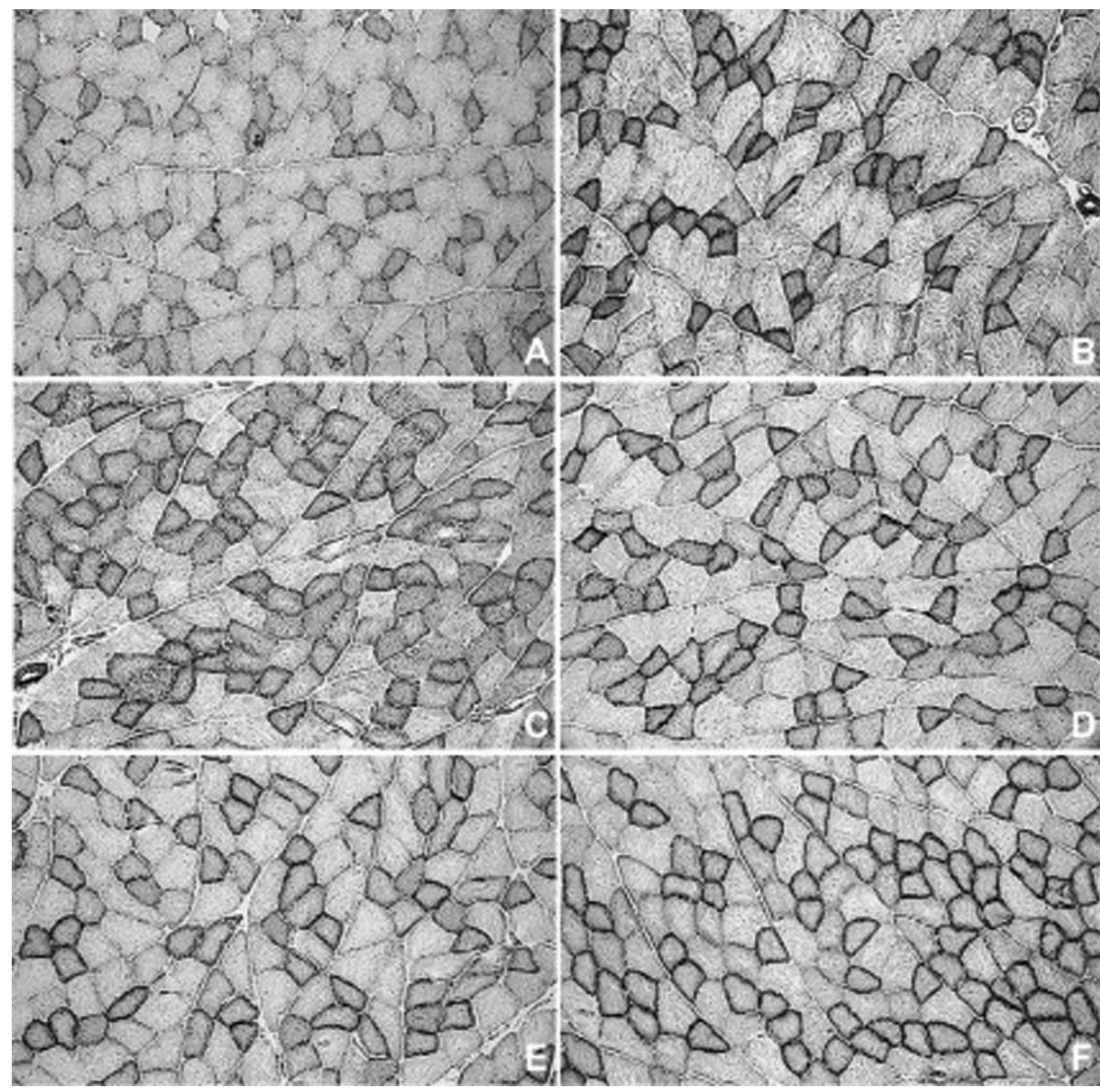

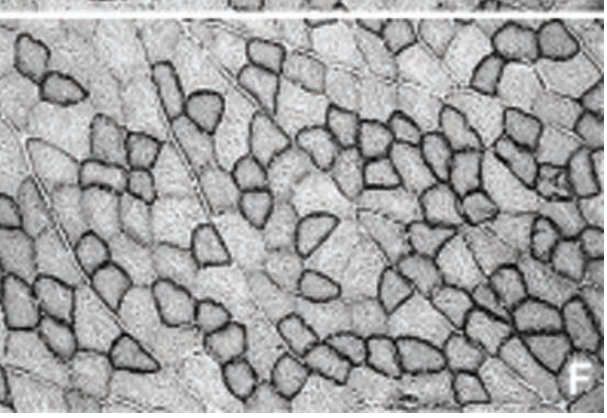

Fig. 2. Cross-sectional of rat gastocnemius muscle fibers. A) Standard Diet and Sedentary;

B) Standard Diet and Exercised;

C) Hypercholesterolemic Diet and Sedentary;

D) Hypercholesterolemic Diet and Exercised;

E) Hypercholesterolemic Diet, Sedentary and Simvastatin;

F) Hypercholesterolemic Diet, Exercised and Simvastatin. NADH-TR. $200 \mathrm{X}$.

It is notable the irregular distribution of the reaction product (B,D,E,F). Amorphous formazan aggregates in the subsarcolemma position (B,D,E,F).

\section{DISCUSSION}

The histological findings revealed that the lipid changes did not induce alterations in the histology of the gastrocnemius muscle in these animals, as animals fed either the standard diet or hypercholestolemic diet and performed exercise exhibited similar muscle alterations. Ciabattari et al. (2005) found that animals submitted to a hypercaloric diet and swimming aerobic exercise exhibited histological muscle changes that occurred regardless of the diet ingested. In fact, muscle alterations in response to physical exercise have also been reported for the soleus muscle in rats exercised through swimming and on a treadmill (Camargo Filho et al., 2005; 2006). The authors of these studies found alterations in the shape of the muscle fibers as well as the presence of degenerative inflammatory processes, which were attributed to mechanisms of adaptation to exercise in the muscle tissue.
In addition, morphological alterations were also found in the animals that received statin. Frequency analysis revealed that some alterations were more frequent (alterations in fiber shape and atrophic fibers) as well as different (presence of splitting) from those observed in the exercised animals, which demonstrates the myotoxic activity that statins possess.

A number of studies suggest a relationship between muscle injury and reduction in the production of ubiquinone (cytochrome Q10), an intermediary of cholesterol synthesis, as this coenzyme is present in the mitochondria, acting on the electron transport chain and, therefore, a reduction in its concentration may be associated to a compromised energy supply for cell maintenance (Bergman et al., 2003; Westwood et al., 2005; Kucharská et al., 2007). However, there is controversy regarding this mechanism, as a reduction in 
ubiquinone levels and alterations in the mitochondria of degenerated fibers have been found with no evidence of muscle injury, thereby suggesting that a reduction in ubiquinone is not the primary factor of muscle injury (Lamperti et al., 2005; Schaefer et al., 2004).

In the present study, the histochemical analysis revealed alterations in NADH activity in the sedentary animals that received statin, which exhibited more accentuated formazan reactions than the sedentary and exercised animals that did not take the medication. This suggests that the muscle injuries found in these animals may be related to the influence of this medication on the cellular respiration mechanism.

When the administration of simvastatin was associated to physical exercise it was observed a greater frequency of muscle alterations. According to Seachrist et al., the administration of cerivastatin concomitant to physical exercise exacerbated injuries in the gastrocnemius muscle, characterized by the occurrence of internalized nuclei, fragmentation of the sarcoplasm, vacuoles, the presence of inflammatory infiltrates, degeneration and mitochondria injury, mainly in type II fibers. These findings are similar to those of the present study. According to the authors, such alterations may be related to energy depletion or the impaired use of energy substrate; thus, the mitochondrial degeneration appears to be the initial event in statin-induced muscle degeneration.

Thompson et al. and Franc et al. (2003) also detected the exacerbation of muscle injuries stemming from the use of statin associated to physical exercise. These authors found an increase in CK and exacerbated muscle injuries in $46 \%$ of patients, respectively. Urso et al. (2005) analyzed muscle samples from healthy human subjects submitted to clinical doses of statin and eccentric exercise and found a greater expression of the ubiquitin proteosome pathway gene, indicating that this association alters muscle response to exercise by interrupting the balance between protein degradation and repair.

In the present study, the histochemical analysis revealed that the medicated and exercised animals exhibited the greatest number of fibers with amorphous formazan aggregates, located alongside fibers with a loss of enzyme activity, thereby suggesting that, due to the energy demands of the organism, physical exercise may overload the mitochondria of muscle fibers, especially glycolitic fibers, considering the selective and myotoxic action of statins (Schaefer et al.).

The morphometric analysis revealed no statistically significant differences in muscle fiber diameter between groups. Generally, the practice of physical exercise leads to a process of hypertrophy in muscle fibers. Thus, the results of the present study may be related to the low intensity of the exercise employed, as hypertrophy is an adaptation to physical overload. Moreover, the morphometric results do not support the affirmation that the administration of statin associated to physical exercise is related to an interruption in the balance between protein degradation and repair (Urso et al.), as this would trigger a reduction in fiber diameter. This finding may also be related to the exercise intensity employed in the present study, suggesting that further studies should be carried out with the aim of analyzing the influence of different exercise intensities on the musculature of animals under treatment with statins.

In summary, the results obtained in the present study indicate that the administration of simvastatin was injurious to the gastrocnemius muscle in sedentary rats and the association of this medication to physical exercise on a treadmill led to an increase in muscle injury.

BONFIM, M. R.; CAMARgo FILHO, J. C. S.; VANDERLEI, L. C. M.; PADULlA, S. A. T.; ACCIOLY, M. F.; SOUZA, R. S. D. \& AZOUBEL, R. Respuestas musculares de la asociación de estatina y ejercicio físico aeróbico en ratas. Int. J. Morphol., 27(4):1155-1161, 2009.

RESUMEN: El ejercicio físico y las estatinas, son intervenciones recomendadas para el tratamiento de la dislipidemia y están independientemente asociadas con la ocurrencia de lesiones musculares. El objetivo fue analizar el efecto del ejercicio aeróbico asociado al uso de la sinvastatina en la morfología del músculo gastrocnemio. 30 ratas macho Wistar fueron divididos en 6 grupos, de los cuales 2 recibieron ración padrón, sedentarios, ejercitados y 4 recibieron dieta con alto nivel de colesterol, sedentarios con y sin medicamento, ejercitados con y sin medicamentos. La dieta fue elaborada a partir de una dieta padrón aumentada de colesterol y aceite de coco. La Sinvastatina (20 mg) fue administrada por 5 días por semana durante 8 semanas $(20 \mathrm{mg} / \mathrm{kg})$, junto al entrenamiento aeróbico en la estera $(9,75 \mathrm{~m} / \mathrm{min})$ por $60 \mathrm{minutos}$ por día. El músculo gastrocnemio colectado fue cortado y colorido por el método Hematoxilina-Eosina y sometido a una reacción histoquímica para verificar la actividad mitocondrial. Los datos fueron analizados utilizando el test t pareado, análisis de la variancia e Pos-Hoc de Scheffé, adoptándose $\mathrm{p}<0,05$. Se verifico la presencia de alteraciones histológicas más significativas en los animales medicados y ejercitados, siendo también mayor la frecuencia de ocurrencia. El análisis histoquímica apunto que los grupos medicados presentaron fibras con actividad mitocondrial más intensa, al lado de fibras con pérdida de reacción. Los resultados de la morfometría no mostraron diferencias significativas entre los grupos estudiados. Se puede sugerir que la simvastatina es un medicamento que lleva a la ocurrencia de lesiones musculares e que su administración concomitante con la práctica de actividad física puede exacerbar estas lesiones, pudiendo tal hecho, estar relacionado con la respiración celular.

PALABRAS CLAVE: Inibidor Hidroxymethilglutaril CoA Reductasa; Ejercicio; Músculo Esquelético. 


\section{REFERENCES}

Armitage, J. The safety of statin in clinical practice. Lancet, 370(9601):1781-90, 2007.

Bergman, M.; Salman, H.; Djaldetti, M.; Alexandrova, S.; Punsky, I.; Bessler, H. Ultrastructure of mouse striated muscle fibers following pravastatin administration. $J$. Muscle Res. Cell Motil., 24:417-20, 2003.

Camargo Filho, J. C. S.; Vanderlei, L. C. M.; Camargo, R. C. T.; Francischeti, F. A.; Belangero, W. D. \& Dal Pai, V. Efeitos do esteróide anabólico nandrolona sobre o músculo sóleo de ratos submetidos a treinamento físico através de natação: estudo histológico, histoquímico e morfométrico. Rev. Bras. Med. Esporte, 12(5):243-7, 2006.

Camargo Filho, J. C. S.; Vanderlei, L. C. M.; Camargo, R. C. T.; Oliveira, D. A. R.; Oliveira Júnior, A. S.; Dal Pai, V. \& Belangero, W. D. Análise histológica, histoquímica e morfométrica do músculo sóleo de ratos submetidos a treinamento físico em esteira rolante. Arq. Ciênc. Saúde, 12(3):196-9, 2005.

Ciabattari, O.; Dal Pai, A. \& Dal Pai, V. Effect of swimming associated with diet on the anterior tibial muscle of rats: morphological and hystochemical study. Rev. Bras. Med. Esporte, 11(2):119e-123e, 2005.

Franc, S.; Dejager, S.; Bruckert, E.; Chauvenet, M.; Giral, P. \& Turpin, G. A comprehensive description of muscle symptoms associated with lipid-lowering drugs. Cardiovasc. Drugs Ther., 17(5-6):459-65, 2003.

Kearns, A. K.; Bilbie, C. L.; Clarkson, P. M.; White, C. M.; Sewright, K. A.; O’Fallon, K. S.; Gadarla, M. \& Thompson, P. D. The creatine kinase response to eccentric exercise with atorvastatin $10 \mathrm{mg}$ or $80 \mathrm{mg}$. Atherosclerosis, 200(1):121-5, 2008.

Kucharská, J.; Gvozdjáková, A. \& Simko, F. Simvastatin decreased coenzyme Q in the left ventricle and skeletal muscle but not in the brain and liver in L-NAME-induced hypertension. Physiol. Res., 56(2):S49-S54, 2007.

Lamperti, C.; Naini, A. B.; Lucchini, V.; Prelle, A.; Bresolin, N.; Moggio, M.; Sciacco, M.; Kaufmann, P. \& DiMauro, $\mathrm{S}$. Muscle coenzyme Q10 level in statin-related myopathy. Arch. Neurol., 62:1709-12, 2005.

Padulla, T. S. A.; Azoubel, R.; Bonfim, R. M.; Accioly, F.
M.; Camargo Filho, S. J. C.; Padovani, J. A. Brandão, A. C. \& Souza, S. D. R. Effects of statin and aerobic physical exercise association in the cardiomyocites of the rat. Morphometric study. Int. J. Morphol., 27(1):83-8, 2009.

Schaefer, W. H.; Lawrence, J. W.; Loughlin, A. F.; Stoffregen, D. A.; Mixson, L. A.; Dean, D. C.; Raab, C. E.; Yu, N. X.; Lankas, G. R. \& Frederick, C. B. Evaluation of ubiquinone concentration and mitochondrial function relative to cerivastatin-induced skeletal myopathy in rats. Toxicol. Appl. Pharmacol., 194:10-23, 2004.

Seachrist, J. L.; Loi, C. M.; Evans, M. G.; Criswell, K. A. \& Rothwell, C. E. Roles of exercise and pharmacokinetics in cerivastatin-induced skeletal muscle toxicity. Toxicol. Sci., 88(2):551-561, 2005.

Sirvent, P.; Mercier, J. \& Lacampagne, A. New insights into mechanisms of statin-associated myotoxicity. Curr. Opin. Pharmacol., 8(3):333-8, 2008.

Sociedade Brasileira de Cardiologia. IV Diretriz Brasileira sobre dislipidemias e prevenção da aterosclerose: Departamento de Aterosclerose da Sociedade Brasileira de Cardiologia. Arq. Bras. Cardiol., 88(S1):2-19, 2007.

Thompson, P. D.; Zmuda, J. M.; Domalik, L. J.; Zimet, R. J.; Staggers, J. \& Guyton, J. R. Lovastatin increases exercised-induced skeletal muscle injury. Metabolism, 46(10):1206-10, 1997.

Tomlinson, S. S. \& Mangione, K. K. Potential adverse effects of statins on muscle. Phys. Ther., 85(5):459-65, 2005.

Urso, M. L.; Clarkson, P. M.; Hittel, D.; Hoffman, E. P.; Thompson, P. D. Changes in ubiquitin proteasome pathway gene expression in skeletal muscle with exercise and statins. Asterioscler. Thromb. Vasc. Biol., 25:25602566, 2005.

Westwood, F. R.; Bigley, A.; Randall, K.; Marsden, A. M.; Scott, R. C. Statin-induced muscle necrosis in the rat: distribution, development, and fibre selectivity. Toxicol. Pathol., 33(2):246-57, 2005.

Correspondence to:

José Carlos Silva Camargo Filho

FCT/Unesp - Departamento de Fisioterapia

Rua Roberto Simonsen, 305; CEP 19060-900 - Presidente

Prudente/SP, Brazil

Phone: +55 1832295388 - Ext: 5466 / Fax: +55 1832295353

E-mail: camargo@fct.unesp.br

Received: 22-06-2009

Accepted: 15-10-2009 
